\title{
Interactive comment on "Why models perform differently on particulate matter over East Asia? - A multi-model intercomparison study for MICS-Asia III” by Jiani Tan et al.
}

Jiani Tan et al.

jsfu@utk.edu

Received and published: 15 February 2020

Please review the authors' responses, revised manuscript, and supplementary material in the attached files.

Please also note the supplement to this comment: https://www.atmos-chem-phys-discuss.net/acp-2019-392/acp-2019-392-AC1supplement.pdf

Interactive comment on Atmos. Chem. Phys. Discuss., https://doi.org/10.5194/acp-2019-392, 2019. 